\title{
Kemampuan Informasi Komponen Arus Kas Dan Laba Dalam Memprediksi Arus Kas Masa Depan
}

\author{
Yuniep Mudjati Suaidah \\ STIE PGRI Dewantara Jombang \\ Korespondensi: Yunip.dewantara@gmail.com
}

Diserahkan: 22 Juli 2017, Direvisis: 30 Juli 2017 Diterima: 14 Agustus 2017

\begin{abstract}
The financial statements are one of the important information issued by the company to investors in the capital market, where the main focus of the financial statements is on the income statement. This study aims to determine whether the information component of cash flow (cash flow operating cash flow investment, cash flow financing and profit) has the ability to predict future cash flows partially and simultaneously. This research uses a quantitative descriptive approach. The population used is the audited financial statements of the Insurance Sector Service Companies Listed on IDX Year 2010-2014 and the samples taken are 10 companies for 5 years reporting the complete financial statements. Sampling method using purposive sampling technique. From the research result, it can be concluded that partially, operating cash flow capability, investment cash flow and profit variable have an effect on to future cash flow. While the cash flow of funding does not affect the future cash flow. Simultaneously the components of cash flows and earnings also have a significant effect on future cash flows.
\end{abstract}

Keywords: Flow, Cash, Operation, Investment, Profit.

\begin{abstract}
Abstrak
Laporan keuangan merupakan salah satu informasi penting yang dikeluarkan perusahaan kepada para investor di pasar modal, dimana fokus utama laporan keuangan tersebut adalah pada laporan laba rugi. Penelitian ini bertujuan untuk mengetahui apakah informasi komponen arus kas (arus kas operasi arus kas investasi, arus kas pendanaan dan laba) memiliki kemampuan dalam memprediksi arus kas masa depan secara parsial dan simultan. Jenis penelitian ini menggunakan pendekatan deskriptif kuantitatif. Populasi yang digunakan adalah laporan keuangan yang sudah diaudit Perusahaan Jasa Sektor Asuransi Yang Terdaftar di BEI Tahun 2010-2014 dan sampel yang diambil adalah 10 perusahaan yang selama 5 tahun melaporkan laporan keuangan secara lengkap. Metode pengambilan sampel menggunakan teknik purposive sampling. Dari hasil penelitian diperoleh kesimpulan bahwa secara parsial, kemampuan arus kas operasi, arus kas investasi dan variabel laba berpengaruh terhadap arus kas masa depan. Sedangkan arus kas pendanaan tidak berpengaruh terhadap arus kas masa depan. Secara simultan komponen arus kas dan laba juga berpengaruh secara signifikan terhadap arus kas masa depan.
\end{abstract}

Kata kunci: Arus, Kas, Operasi, Investasi, Laba.

\section{A. PENDAHULUAN}

Perkembangan dunia usaha yang sangat pesat menuntut perusahaan-perusahaan di Indonesia untuk meningkatkan kinerjanya agar tetap bertahan dan semakin berkembang.Umar (2001). Jika kinerja perusahaan baik, berarti perusahaan mudah untuk menggalang dana dari investor maupun kreditur, terutama bagi perusahaan publik. Laporan keuangan tersebut menjadi bahan pertimbangan bagi investor maupun kreditur dalam mengambil keputusan karena tujuan dari laporan keuangan adalah menyediakan informasi yang menyangkut posisi keuangan, kinerja, dan perubahan posisi keuangan suatu perusahaan yang bermanfaat bagi sejumlah besar pemakai dalam pengambilan keputusan ekonomi (Sumarjo, 2010) 
Dalam setiap pengambilan keputusan investasi apakah keputusan akan membeli, menjual, atau pun tetap mempertahankan investasi pada suatu perusahaan, para investor dan kreditur akan dihadapkan pada situasi ketidakpastian resiko dimasa depan. Pengungkapan kualitas kinerja perusahaan dituangkan dalam publikasi laporan keuangan. Laporan keuangan merupakan salah satu informasi penting yang dikeluarkan perusahaan kepada para investor di pasar modal, dimana fokus utama laporan keuangan tersebut adalah pada laporan laba rugi (Susilowati, 2011). Namun ternyata dalam perkembangannya, informasi laba ternyata mempunyai beberapa kelemahan, sehingga kemudian arus kas lebih banyak dipakai sebagai dasar pengambilan keputusan Sri Mar'ati (2009). Kemampuan informasi akuntansi untuk memenuhi tujuan laporan keuangan dalam proses pengambilan keputusan (Yuwana dan Jogi, 2014). Investor dapat memperoleh informasi akuntansi dari laporan keuangan. Menurut Pernyataan Standar Akuntansi Keuangan Nomor 1tahun 2015 laporan keuangan merupakan sarana acuan bagi kreditur dan investor dalam pengambilan keputusan.Pernyataan Standar Akuntansi Keuangan Nomor 1tahun 2015 paragraf 7 disebutkan bahwa laporan keuangan yang lengkap terdiri dari komponen-komponen berikut ini: (a) neraca, (b) laporan laba rugi, (c) laporan perubahan posisi keuangan (yang dapat disajikan dalam berbagai cara, sebagai contoh, sebagai laporan arus kas, atau laporan arus dana), (d) catatan dan laporan lain. Nanun, laporan keuangan tidak mencakup item tertentu seperti laporan manajemen, analisis dan pembahasan umum oleh manajemen.

Laporan laba rugi merupakan laporan utama untuk mengukur kinerja dan dapat menunjukan prestasi dari suatu perusahaan selama periode tertentu. Informasi yang terkandung dalam laporan laba rugi dapat digunakan untuk menilai ketidakpastian arus kas masa depan karena dapat menjadi dasar untuk memprediksi kinerja perusahaan di masa depan (Yuwana dan Jogi, 2014). Laporan arus kas merupakan laporan yang berisi informasi aliran kas masuk dan aliran kas keluar dari perusahaan selama periode tertentu. Menurut Pernyataan Standar Akuntansi Keuangan Nomor 2 tahun 2015 informasi yang disajikan dalam laporan arus kas jika digunakan dalam kaitannya dengan laporan keuangan lain dapat berguna untuk menilai kemampuan perusahaan dalam menghasilkan kas dan setara kas dan memungkinkan para pengguna informasi untuk mengembangkan model, untuk menilai, dan membandingkan nilai sekarang dari arus kas masa depan (future cash flow) dari berbagai perusahaan (Mufidah, 2017)

Peraturan tentang laporan arus kas yang merupakan salah satu bagian dari laporan keuangan, usianya relatif lebih muda jika dibandingkan dengan peraturan neraca dan laporan laba-rugi, Pernyataan Standar Akuntansi Keuangan Nomor 2tahun 2015 yang menandai diwajibkannya laporan arus kas dalam pelaporan keuangan. Arus kas yang sehat begitu vital karena perusahaan dalam menjalankan aktivitasnya perusahaan membutuhkan kas, bukan laba bersih. Gambaran menyeluruh mengenai penerimaan dan pengeluaran kas hanya dapat diperoleh dari laporan arus kas, tetapi bukan berarti laporan arus kas menggantikan neraca atau pun laporan laba-rugi, melainkan saling melengkapi sebagai sarana pengambilan keputusan yang lebih baik. Laba yang maksmimal merupakan salah satu tujuan utama suatu perusahaan karena dengan laba yang maksimal akan menentukan kelangsungan hidup suatu perusahaan itu sendiri. (Pujiati, 2015)

Laporan laba rugi dan laporan arus kas merupakan salah satu informasi akuntansi yang dapat digunakan oleh para investor untuk menilai kinerja dari suatu perusahaan dalam memberdayakan aset-aset yang dimilikinya secara maksimal(Respati dan Yandono ,2008). Perubahan kenaikan atau penurunan kinerja keuangan akan memberikan dampak terhadap kebijakan keuangan untuk kegiatan selanjutnya seperti kebijakan penetapan deviden, pembayaran utang, penyisihan atau melakukan investasi dan menjaga kelangsungan operasi. 
Informasi mengenai laba selain untuk menilai kinerja manajemen juga digunakan untuk menaksir risiko dalam investasi dan kredit. Besarnya laba tercermin dalam Laporan Laba/ Rugi. Hery (2009:100) mendefinisikan Laporan Laba/ Rugi sebagai laporan utama untuk melaporkan kinerja dari suatu perusahaan selama periode tertentu. Laporan rugi-laba bermanfaat bagi para pemakai laporan keuangan dalam memprediksi arus kas masa depan (Martani, 2012:111).

Namun, terdapat beberapa hasil penelitian yang mendukung nilai relevansi laba dalam memprediksi arus kas masa depan perusahaan. Yuwana dan Jogi (2014) menyatakan bahwa laba bersih secara parsial memiliki kemampuan untuk memprediksi arus kas operasi masa depan. Demikian pula dengan arus kas operasi secara parsial juga berpengaruh signifikan dalam menjadi prediktor bagi arus kas operasi masa depan.

Dahler dan Febrianto (2006) bahwa arus kas operasi tahun berjalan memiliki kemampuan yang lebih baik dibanding dengan laba dalam memprediksi arus kas operasi masa depan. Dalam hal ini Arus kas masa depan dapat ditingkatkan dengan mengelola arus kas yang ada pada saat ini dengan sebaik mungkin untuk kegiatan investasi, operasional dan pendanaan Kusumawardana, et al (2013). Hasilnya Jika kegiatan pendanaan dilakukan tidak untuk kegiatan yang produktif yang bisa menghasilkan keuntungan dimasa depan maka investor dapat menunda investasinya. Hal ini dilakukan karena arus kas pendanaan berpengaruh negatif terhadap arus kas masa depan.

Berdasarkan perbedaan-perbedaan hasil penelitian mengenai kemampuan laba dan arus kas dalam memprediksi arus kas masa depan, maka penelitian ini bermaksud menguji kembali kemampuan tersebut dengan mengelompokkan perusahaan yang melaporkan laba positif dan laba negatif untuk melihat apakah akan diperoleh simpulan hasil yang sama.

Rumusan masaah yang diangkat pada penelitian ini adalah: 1) Apakah informasi komponen arus kas (arus kas operasi arus kas investasi, arus kas pendanaan dan laba) memiliki kemampuan dalam memprediksi arus kas masa depan secara parsial? 2) Apakah informasi komponen arus kas (arus kas operasi arus kas investasi, arus kas pendanaan dan laba) memiliki kemampuan dalam memprediksi arus kas masa depan secara simultan?

Diharapkan, hasil dari penelitian ini akan bermanfaat bagi banyak pihak antara lain para investor, akademisi dan peneliti selanjutnya.

\section{B. LANDASAN TEORI \\ Penelitian Terdahulu}

Yuwana dan Jogi (2014) menyatakan bahwa laba bersih secara parsial berpengaruh signifikan dalam menjadi predictor bagi arus kas operasi masa depan. Demikian pula dengan arus kas operasi secara parsial juga berpengaruh signifikan dalam menjadi prediktor bagi arus kas operasi masa depan. PenelitianYolanda dan Rahmat (2006) tentang kemampuan prediktif earning dan arus kas dalam memprediksi arus kas masa depan menunjukkan bahwa Arus kas operasi tahun berjalan memiliki kemampuan lebih baik dibandingkan dengan laba dalam memprediksi arus kas operasi masa yang akan datang. Sedangkan Kusumawardana et al (2013) yang melakukan penelitian tentang dengan judul Laba dan Arus Kas Terhadap Kemampuan Memprediksi Arus Kas Masa Depan menyatakan bahwa Arus kas pendanaan meningkat, maka arus kas pada masa depan diprediksi mengalamiPenurunan.

Junaidi (2015) yang melakukan penelitian tentang Laba dan Arus Kas Dalam Memprediksi Laba dan Arus Kas Masa Mendatang dan Pola Harga Saham menyatakan bahwa laba dapat memprediksi laba masa depan, harga saham sekarang dapat memprediksi harga sahammendatang dan arus kas runtun waktu dapat memprediksi arus kas mendatang. Sticce, et al (2014) dalam penelitiannya yang berjudul cash flow management and manufacturing firm financial performance menyatakan bahwaLaba dan arus kas berpengaruh pada nilai perusahaan. 


\section{Laporan Keuangan}

Menurut Pernyataan Standar Akuntansi Keuangan Nomor 1 tahun 2015, laporan keuangan merupakan suatu penyajian terstruktur dari posisi keuangan dan kinerja suatu perusahaan. Setiap perusahaan dapat melaporkan keadaan dan perkembangan perusahaannya, salah satunya melalui data-data keuangan yang tercantum dalam laporan keuangan.Menurut Hery (2009:2) laporan keuangan adalah laporan akuntansi utama yang mengkomunikasikan informasi keuangan kepada pihak-pihak yang berkepentingan, sebagai bahan pertimbangan dalam pengambilan keputusan ekonomi.

Menurut Rudianto (2012:20) tujuan pelaporan keuangan adalah:

1. Pelaporan keuangan berguna untuk memberikan informasi bagi para pengambil keputusan investsi dan kredit yang mempunyai cukup pengertian dalam kegiatan ekonomi dan bisnis.

2. Pelaporan keuangan berguna untuk memberikan informasi yang membantu investor dan kreditur saat ini dan yang potensial serta pemakai-pemakai lain dalam menilai jumlah, waktu, dan ketidakpastian arus kas masa depan.

3. Pelaporan keuangan berguna untuk memberikan informasi kepada pemakai laporan untuk mengestimasi potensi perusahaan dalam menghasilkan laba di masa depan.

\section{Arus Kas}

Menurut Pernyataan Standar Akuntansi Keuangan Nomor 2 tahun 2015 Laporan Arus Kas " Arus kas adalah arus masuk dan arus keluar kas atau setara kas. Arus masuk kas (cash inflows) merupakan transaksi yang mengakibatkan kenaikan kas". Sedangkan arus kas keluar (cash outflows) merupakan transaksi yang menyebabkan penurunan kas.Arus kas merupakan sejumlah uang yang keluar dan yang masuk sebagai akibat dari aktivitas perusahaan atau dengan kata lain arus kas adalah aliran kas yang terdiri dari kas masuk kedalam perusahaan dan kas keluar perusahaan serta jumlah saldonya setiap periode. Sedangkan Harahap (2008:205) mendefinisikan kas sebagai pos atau asset yang paling lancar dan paling diminati semua orang, paling mudah dicuri dan dimanipulasi.

\section{Tujuan dan Kegunaan Laporan Arus Kas}

Menurut Kieso et al (2010), informasi dalam laporan arus kas sebuah perusahaan dapat membantu para investor, kreditur, dan pihak lainnya guna menilai: 1) Kemampuan perusahaan untuk menghasilkan arus kas di masa depan. 2) Kemampuan perusahaan untuk membagikan dividen dan memenuhi kewajibannya, 3) Penyebab perbedaan antara laba bersih dan arus kas bersih dari kegiatan operasi, 4) Transaksi- transaksi pendanaan dan investasi kas dan non-kas selama suatu periode tertentu.

\section{Komponen Arus Kas}

Laporan arus kas menurutPernyataan Standar Akuntansi Keuangan Nomor 2 tahun 2015, informasi dalam laporan arus kas dapat diklasifikasikan dalam tiga bagian, yaitu:

1. Arus Kas dari Aktivitas Operasi. Arus kas dari aktivitas operasi adalah arus kas yang berasal dari aktivitas penghasil utama pendapatan perusahaan (principal revenueproducing activities) dan aktivitas lain yang bukan merupakan aktivitas investasi dan pendanaan. Arus kas dari aktivitas operasi ini merupakan bagian dari laporan arus kas di mana dilaporkan transaksi kas yang masuk ke dalam penentuan laba bersih. Jumlah arus kas yang berasal dari aktivitas operasi merupakan indikator yang menentukan apakah dari operasinya perusahaan dapat menghasilkan arus kas yang cukup untuk melunasi pinjaman, memelihara kemampuan operasi perusahaan, membayar dividen dan melakukan investasi baru tanpa mengandalkan pada sumber pendanaan dari luar. Informasi mengenai unsur tertentu arus kas historis bersama dengan informasi lain, berguna dalam memprediksi arus kas operasi masa depan. 
2. Arus Kas dari Aktivitas Investasi. Arus kas dari aktivitas investasi adalah arus kas dari perolehan dan pelepasan aktiva jangka panjang serta investasi lain yang tidak termasuk setara kas. Arus kas dari aktivitas ini merupakan bagian dari laporan arus kas di mana dilaporkan aktivitas yang melibatkan penerimaan kas dari penjualan investasi, aktiva tetap, dan aktiva tidak lancar lainnya, dan pembayaran kas untuk akuisisi investasi, aktiva tetap, dan aktiva tidak lancar lainnya. Pengungkapan terpisah arus kas yang berasal dari aktivitas investasi perlu dilakukan sebab arus kas tersebut mencerminkan penerimaan dan pengeluaran kas sehubungan dengan sumber daya yang bertujuan untuk menghasilkan pendapatan dan arus kas masa depan.

3. Arus Kas dari Aktivitas Pendanaan (Financing). Arus kas dari aktivitas pendanaan adalah arus kas yang berasal dari aktivitas yang mengakibatkan perubahan dalam jumlah serta komposisi modal dan pinjaman perusahaan. Arus kas yang berasal dari aktivitas pendanaan merupakan bagian dari laporan arus kas di mana dilaporkan transaksi yang melibatkan penerimaan kas dari penerbitan ekuitas dan surat hutang, dan pembayaran kas untuk dividen, pembelian kembali surat berharga ekuitas, dan penarikan surat hutang. Pengungkapan terpisah arus kas yang timbul dari aktivitas pendanaan perlu dilakukan sebab berguna untuk memprediksi klaim terhadap arus kas masa depan oleh para pemasok modal perusahaan.

Karakteristik laba berkaitan dengan identifikasi sifat dari laba sehingga memungkinkan untuk menganalisis transaksi atau peristiwa yang dapat mempengaruhi laba. Laba adalah pengambilan atas investasi kepada pemilik (Sticce, 2014:240). Salah satu tujuan pelaporan keuangan adalah memberikan informasi keuangan yang dapat menunjukkan prestasi perusahaan dalam menghasilkan laba, sehingga diharapkan para pemakai laporan dapat mengambil keputusan ekonomi yang tepat sesuai dengan kepentingannya.

\section{Kerangka Pemikiran}

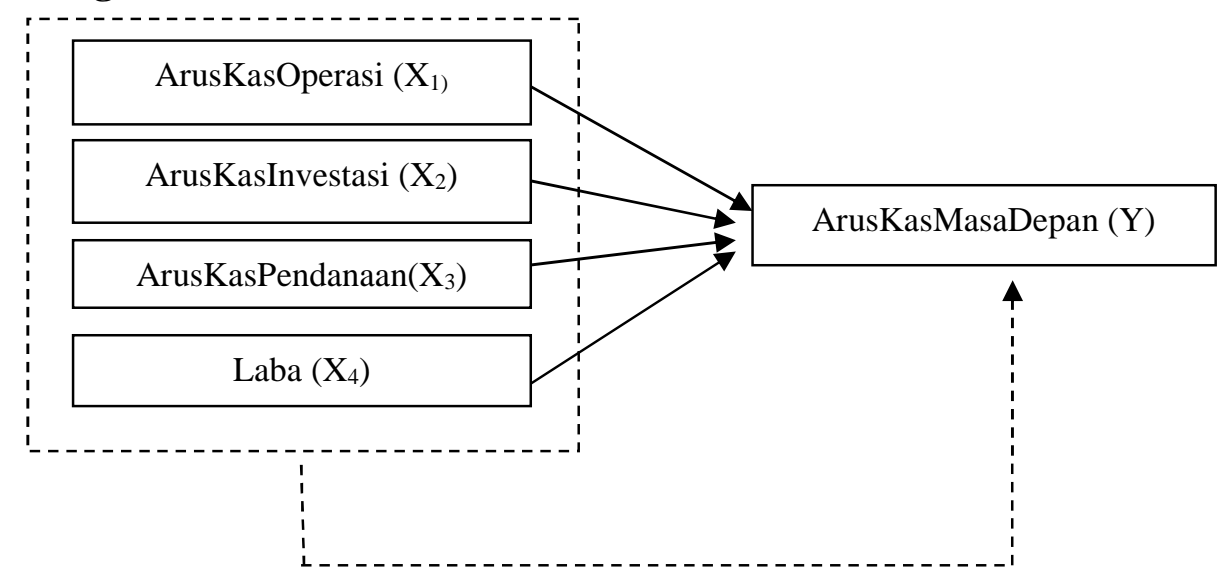

Gambar 1. kerangka Berpikir

Maka, berdasarkan perumusan masalah dan kerangka konseptual di atas, maka hipotesis dalam penelitian ini adalah:

$\mathrm{Ha}_{1}$ : Arus kas operasi mempunyai kemampuan untuk memprediksi arus kas masa depan.

$\mathrm{Ha}_{2}$ : Arus kas investasi mempunyai kemampuan untuk memprediksi arus kas masa depan.

$\mathrm{Ha}_{3}$ : Arus kas pendanaan mempunyai kemampuan untuk memprediksi arus kas masa depan.

Ha4: Laba mempunyai kemampuan untuk memprediksi arus kas masa depan.

Ha5: Komponen arus kas dan laba secara simultan mempunyai kemampuan untuk memprediksi arus kas masa depan.

\section{METODE PENELITIAN}


Penelitian ini menggunakan pendekatan deskriptif kuantitatif yaitu penelitian yang dilakukan untuk mengetahui dan menjelaskan karekteristik variabel yang diteliti dalam suatu situasi.Deskriptif adalah teori paling tidak berisi tentang penjelasan terhadap variabelvariabel yang diteliti, melalui pendefinisian, dan uraian yang lengkap dan mendalam dari berbagai dari berbagai referensi, sehingga ruang lingkup, kedudukan dan prediksi terhadap hubungan antar variabel yang akan diteliti menjadi lebih jelas dan terarah (Sugiyono, 2010:147). Sedangkan kuantitatif adalah metode penelitian yang berlandaskan pada filsafat positifisme, digunakan untuk meneliti pada populasi atau sampel tertentu, teknik pengambilan sampel pada umumnya dilakukan secara random, pengumpulan data menggunakan instrumen penelitian, analisis data bersifat kuantitatif/statistik dengan tujuan untuk menguji hipotesis yang telah ditetapkan (Sugiyono, 2010:13)

\section{Penentuan Populasi dan Sampel}

Populasi dalam penelitian ini adalah laporan keuangan yang sudah diaudit Perusahaan Jasa Sektor Asuransi Yang Terdaftar di BEI Tahun 2010-2014, ( 10 perusahaan yang selama 5 tahun melaporkan laporan keuangan secara lengkap dari tahun $2010-2014$ ).

Metode dalam pengambilan sampel dalam penelitian ini adalah menggunakan purposive sampling dengan tujuan untuk mendapatkan sampel yang representative sesuai dengan kriteria yang telah ditentukan. Selanjutnya sampel dipilih dengan metode purposive sampling, yaitu pemilihan sampel tidak acak yang informasinya diperoleh dengan pertimbangan tertentu (Indriantoro dan Supomo, 2007:131). Kriteria-kriteria yang ditetapkan untuk memilih sampel adalah sebagai berikut : 1) Perusahaan telah go public, 2) Keuangan yang berakhir pada tanggal 31 Desember 2010, 31 Desember 2011, 31 Desember 2012, 31 Desember 2013, dan 31 Desember 2014, 3) Laporan tahunan lengkap, 4) Laporan keuangan telah diaudit.

Maka berdasarkan kriteria diatas, diperoleh sampel sebagai berikut: 1) Asuransi Bina Dana Artha Tbk (ABDA), 2) Asuransi Artha Aman Pratama Tbk (AHAP), 3) Asuransi Multi Artha Guna Tbk (AMAG), 4) Asuransi Bintang Tbk (ASBI), 5) Asuransi Dayin Mitra Tbk (ASDM), 6) Asuransi Jaya Tania Tbk (ASJT), 7) Asuransi Mitra Maparya Tbk (ASMI), 8) Asuransi Ramayana Tbk (ASRM), 9) Lippo General Insurance Tbk (LPGI), 10) Maskapai Reasuransi Indonesia Tbk (MREI), 11) Panin Insurance Tbk (PNIN), 12) Victoria Insurance Tbk (VINS)

\section{Definisi Operasional dan Pengukuran Variabel}

1. Variabel Independen (X), adalah variabel yang yang mempengaruhi atau yang menjadi sebab perubahan atau timbulnya variabel dependen/terikat. (Sugiyono, 2010:39). Yang termasuk dalam variabel ini ini adalah:

a. Arus Kas Operasi $\left(\mathrm{X}_{1}\right)$, yaitu kas yang diperoleh dari aktivitas utama yang menghasilkan pendapatan perusahaan dan aktivitas lain yang bukan merupakan aktivitas investasi dan aktivitas pendanaan.

b. Arus Kas Investasi $\left(\mathrm{X}_{2}\right)$, yaitu kas yang berasal dari perolehan dan pelepasan aktiva jangka panjang serta investasi lain yang tidak termasuk setara kas.

c. Arus Kas Pendanaan $\left(\mathrm{X}_{3}\right)$, yaitu kas yang berasal dari aktivitas yang mengakibatkan perubahan dalam jumlah dan komposisi modal dan pinjaman perusahaan.

d. Laba $\left(\mathrm{X}_{4}\right)$, yaitu laba akuntansi Laba atau rugi selama satu periode sebelum dikurangi beban pajak (PSAK No.46, 2015)

2. Variabel Dependen (Y), adalah variabel yang dipengaruhi atau menjadi akibat, karena adanya variabel bebas (Sugiyono, 2010:59). Adapun variabel dependen dalam penelitian ini adalah Arus Kas Masa Depan (Y). Arus kas masa depan adalah akumulasi arus kas bersih dari aktivitas operasi, investasi dan pendanaan masa depan.

Data yang digunakan untuk mengukur variabel arus kas operasi adalah data berskala rasio. Data yang digunakan untuk mengukur variabel arus kas investasi adalah data berskala 
rasio. Data yang digunakan untuk mengukur variabel arus kas pendanaan adalah data berskala rasio. Laba sebelum pajak merupakan hasil pengurangan penjualan dengan harga pokok produksi dan biaya operasional. Data yang digunakan untuk mengukur variabel laba bersih adalah data berskala rasio. Data yang digunakan untuk mengukur variabel arus kas masa depan adalah data berskala rasio.

\section{Metode Pengumpulan Data}

Metode pengumpulan data dilakukan dengan cara mencatat variabel-variabel yang digunakan dalam penelitian, yaitu informasi komponen arus kas dan laba pada laporan keuangan Perusahaan Jasa Sektor Asuransi Yang Terdaftar di BEI Tahun 2010-2014. Data penelitian didapatkan dari situs Bursa Efek Indonesia

Setelah melaui uji kelayakan data, selanjutnya data dianalisa dengan menggunakan uji $-t$, uji-F dan analisa regresi berganda untuk mencari model persamaan.

\section{HASIL DAN PEMBAHASAN} berikut:

Dari hasil penelitian yang bersumber dari pengolahan data primer, didapat hasil sebagai

\begin{tabular}{|c|c|c|c|c|c|c|c|c|}
\hline \multicolumn{9}{|c|}{$\begin{array}{c}\text { Tabel 1. Koefisien Regresi } \\
\text { Coefficients }^{\mathrm{a}}\end{array}$} \\
\hline & \multirow{3}{*}{ Model } & \multirow{2}{*}{\multicolumn{2}{|c|}{$\begin{array}{l}\text { Unstandardized } \\
\text { Coefficients }\end{array}$}} & \multirow{3}{*}{$\begin{array}{c}\text { Standardized } \\
\text { Coefficients } \\
\text { Beta }\end{array}$} & \multirow{3}{*}{$\mathrm{t}$} & \multirow{3}{*}{ Sig. } & \multirow{2}{*}{\multicolumn{2}{|c|}{$\begin{array}{l}\text { Collinearity } \\
\text { Statistics }\end{array}$}} \\
\hline & & & & & & & & \\
\hline & & B & $\begin{array}{l}\text { Std. } \\
\text { Error }\end{array}$ & & & & Tolerance & VIF \\
\hline \multirow[t]{5}{*}{1} & (Constant) & .067 & .065 & & 1.033 & .307 & & \\
\hline & Arus Kas Operasi & .458 & .138 & .569 & 3.325 & .002 & .508 & 1.968 \\
\hline & Arus_Kas_Investasi & .424 & .150 & .360 & 2.832 & .007 & .920 & 1.087 \\
\hline & Arus Kas Pendanaan & -.071 & .161 & -.056 & -.444 & .659 & .923 & 1.084 \\
\hline & Laba & -.095 & .148 & -.111 & -.638 & .527 & .495 & 2.022 \\
\hline
\end{tabular}

a. Dependent Variable : Arus_Kas_Masa_Depan

Sumber: Data Primer diolah, 2016

Dari nilai-nilai koefisien di atas, persamaan regresi yang dapat disusun untuk variabel komponen arus kas dan laba adalah $: Y=0,067+0,458 X_{1}+0,424 X_{2}-0,071 X_{3}-0,095 X_{2}+e$

Sedangkan dari hasil pengujian untuk nilai R square, diperoleh hasil sebagai berikut:

Tabel 2. Model Summary

\begin{tabular}{|c|c|c|c|c|c|c|c|c|c|c|}
\hline \multirow[b]{2}{*}{ Mode } & \multirow[b]{2}{*}{$\mathrm{R}$} & \multirow[b]{2}{*}{ R Square } & \multirow[b]{2}{*}{$\begin{array}{l}\text { Adjusted } \\
\text { R Square }\end{array}$} & \multicolumn{7}{|c|}{ Change Statistics } \\
\hline & & & & $\begin{array}{l}\text { Std. Error of } \\
\text { the Estimate }\end{array}$ & $\begin{array}{l}\text { R Square } \\
\text { Change }\end{array}$ & F Change & df1 & df 2 & $\begin{array}{c}\text { Sig. F } \\
\text { Change }\end{array}$ & $\begin{array}{l}\text { Durbin- } \\
\text { Watson }\end{array}$ \\
\hline 1 & $.574^{\mathrm{a}}$ & .329 & .270 & .06638 & .329 & .329 & 4 & 45 & .001 & 1.780 \\
\hline
\end{tabular}

Sumber: Data Primer Diolah, 2016

Dari hasil analisis regresi diperoleh koefisien determinasi sebesar 0,270. Hal ini berarti variasi arus kas operasi, arus kas investasi, arus kas pendanaan dan laba menjelaskan variasi arus kas masa depan sebesar $27 \%$, sedangkan sisanya sebesar $73 \%$ dijelaskan variabel lain yang tidak diteliti.

\section{Kemampuan Arus Kas Operasi Dalam Memprediksi Arus Kas Masa Depan}

Dari tabel 1 (satu) dapat disimpulkan bahwa arus kas operasi(X1) mempunyai nilai signifikansi 0,002 yang berarti nilai ini lebih kecil dari 0,05 . Selain itu, t hitung diperoleh 3,325 > t tabel 2,013. Maka dapat disimpulkan bahwa variabel arus kas operasi secara parsial berpengaruh dan signifikan terhadap arus kas masa depan. 
Hasil ini menolak dengan penelitian yang dilakukan oleh Kusuma (2013) yang menyatakan bahwa arus kas operasi tidak mampu memprediksi arus kas masa depan. Hal ini arus kas operasi mencerminkan tahun berjalan memiliki kemampuan yang lebih baik disbanding dengan laba dalam memprediksi arus kas masa depan.

\section{Kemampuan Arus Kas Investasi Dalam Memprediksi Arus Kas Masa Depan}

Dari tabel 1 (satu) dapat disimpulkan bahwa arus kas investasi (X2) mempunyai nilai signifikansi 0,007 yang berarti nilai ini lebih kecildari 0,05. Selain itu, t hitung diperoleh $2,832>$ t tabel 2,013. Berdasarkan nilai tersebut disimpulkan bahwa arus kas investasi secara parsial berpengaruh namun tidak signifikan terhadap arus kas masa depan.

Hasil ini mendukung dengan penelitian yang dilakukan oleh Kusuma (2013) yang menyatakan bahwa arus kas investasi mampu memprediksi arus kas masa depan. Hal ini karena jika arus kas investasi meningkat, maka arus kas masa depan juga akan mengalami peningkatan.

\section{Kemampuan Arus Kas Pendanaan Dalam Memprediksi Arus Kas Masa Depan}

Dari tabel1 (satu) dapat disimpulkan bahwa arus kas pendanaan (X3) mempunyai nilai signifikansi 0,659 yang berarti nilai ini lebih besar dari 0,05. Selain itu, t hitungdiperoleh $0,444<\mathrm{t}$ tabel 2,013. Berdasarkan nilai tersebut disimpulkan variable arus kas pendanaan secara parsial tidak berpengaruh terhadap arus kas masa depan.

Hasil ini menolak dengan penelitian yang dilakukan oleh Kusuma (2013) yang menyatakan bahwa arus kas pendanaan tidak mampu memprediksi arus kas masa depan.Hal ini arus kas pendanaan mencerminkan tahun berjalan tidak memiliki kemampuan yang lebih baik karena semakin besar arus kas pendanaan semakin berpengaruh dalam arus kas masa depan.

\section{Kemampuan Laba Dalam Memprediksi Arus Kas Masa Depan}

Dari table 1 (satu) dapat disimpulkan bahwa laba (X4) mempunyai nilai signifikansi 0,527 yang berarti nilai ini lebih besar dari 0,05. Selain itu, $t$ hitung diperoleh $-0,638<\mathrm{t}$ tabel 2,014. Berdasarkan nilai tersebut disimpulkan bahwa variable laba secara parsial tidak berpengaruh terhadap arus kas masa depan. Hasil ini mendukung dengan penelitian yang dilakukan oleh Kusuma Wardana (2013) yang menyatakan bahwa laba tidak mampu memprediksi arus kas masa depan. Laba tidak berpengaruh dalam memprediksi arus kas masa depan, hal ini berarti kemampuan perusahaan dalam memperoleh laba pada tahun ini tidak dapat digunakan sebagai alat prediksi arus kas masa depan.

\section{Uji F ( Simultan )}

Uji $\mathrm{F}$ digunakan untuk menguji pengaruh signifikansi secara simultan dari semua variable independen terhadap variable dependen. Hasil pengujian hipotesis dengan menggunakan uji F (Simultan) dapat dilihat pada berikut:

Tabel 2. Analysis of Variance

\begin{tabular}{lrrrrr}
\hline Model & \multicolumn{1}{c}{ Sum Of } & & & & \\
Squares & df & & Mean Square & F & \multicolumn{1}{c}{ Sig. } \\
\hline 1 Regression & .097 & 4 & .024 & 5.524 & $.001_{\mathrm{a}}$ \\
Residual & .198 & 45 & .004 & & \\
Total & .296 & 49 & & & \\
\hline
\end{tabular}

a. Predictors : (Constant), Laba, Arus_Kas_Investasi,Arus_Kas_Pendanaan,Arus_Kas_Operasi

b. Dependent variable : Arus_Kas_Masa_Depan

Sumber: Data Primer Diolah, 2016

Dari uji ANOVA atau $\mathrm{F}$ test, diperoleh $\mathrm{F}$ hitung sebesar 5,524 dengan tingkat signifikansi 0,001, sedangkan $\mathrm{F}$ table sebesar 2,579 dengan signifikansi 0,05. Berdasarkan hasil tersebut dapat disimpulkan bahwa kemampuan komponen arus kas dan laba secara bersama-sama atau secara simultan mampu dan signifikan terhadap arus kas masa depan 


\section{E. PENUTUP}

Dari hasil penelitian diperoleh kesimpulan bahwa secara parsial kemampuan arus kas operasi berpengaruh terhadap arus kas masa depan (nilai $\mathrm{t}=3,325$ ). Demikian juga dengan arus kas investasi yang berpengaruh terhadap arus kas masa depan (nilai $\mathrm{t}=2,832$ ). Sedangkanarus kas pendanaan tidak berpengaruh terhadap arus kas masa depan (nilai $\mathrm{t}=$ $0,444<\mathrm{t}$ tabel 2,013). Variabel laba juga berpengaruh signifikan pada variable arus kas masa depan (nilai $\mathrm{t}=0,638<\mathrm{t}$ tabel 2,014). Akan tetapi, secara simultan komponen arus kas dan laba berpengaruh secara signifikan terhadap arus kas masa depan, yang ditunjukkan oleh nilai signifikansi $\mathrm{F} 0,001<0,05$ dan $\mathrm{F}$ hitung 5,524 > F tabel 2,579. Hasil ini di dukung dari nilai koefisien determinasi R Square sebesar 0,270 yang menunjukkan bahwa variabel independen komponen arus kas dan laba mampu menjelaskan sebanyak $27 \%$ variasi atau perubahan dari variabel dependen yaitu arus kas masa depan.

Berdasarkan hasil penelitian tersebut, maka disarankan kepada perusahaan bahwa salah satu cara meningkatkan arus kas masa depan adalah dengan meningkatkan penjualan dan melakukan efisiensi untuk mengurangi biaya. Kegiatan investasi dapat dilakukan dengan menambah aktiva produktif untuk meningkatkan produksi, sedangkan pendanaan dapat dikendalikan dengan mengendalikan pinjaman bank dan pembayaran dividen. Selain itu, bagi investor disarankan untuk mencermati kegiatan perusahaan. Apabila kegiatan aktifitas operasi, investasi, dan pendanaan dilakukan tidak untuk kegiatan yang produktif yang bisa menghasilkan keuntungan dimasa depan maka investor dapat menunda investasinya.

\section{DAFTAR PUSTAKA}

Dahler, Yolanda dan Febrianto, Rahmat, (2006), "Kemampuan Prediktif Earnings dan Arus Kas dalam Memprediksi Arus Kas Masa Depan", Simposium Nasional Akuntansi 9 Padang.

Fuji Sri Mar'ati. (2009). Pengaruh Laba Akuntansi dan Arus Kas Terhadap Abnormal Return Saham. Among Makarti, Vol. 2, No. 4,

Harahap, S. S. 2007. Kerangka Teori dan Tujuan Syariah Akuntansi. Edisi I. Penerbit : PT Raja GrafindoPersada. Jakarta.

Hery. 2009. Akuntansi Keuangan Menengah I. Edisi I, Bumi Aksara, Jakarta.

Ikatan Akuntan Indonesia .2015 .Pernyataan Standar Akuntansi Keuangan. Edisi 2015. Penerbit :SalembaEmpat . Jakarta.

Indrianto, N. Bambang, S. 2007, Metode Peneltian Bisnis Akuntansi dan Manajemen. BPFE, Yogjakarta.

Kieso, Donal E, Weygandt, Jerry J,and Warfield, Terry D. 2010. Akuntansi Intermediate, Edisi Ketiga Belas, Jilid 1, Diterjemahkan oleh Yati Sumiharti dan Suryadi Erlangga, Jakarta.

Kusumawardana, Sujono, dan Lestari. (2013). Pengaruh Laba dan Arus Kas Terhadap Kemampuan Memprediksi Arus Kas Masa Depan (Studi Pada Perusahaan yang Masuk dalam LQ 45 di Bursa Efek Indonesia)

Mufidah, E. (2017). Analisis Laba, Arus Kas Operasi Dan Nilai Buku Ekuitas Terhadap Harga Saham. Eksis: Jurnal Riset Ekonomi dan Bisnis, 12(1 Apr).

Martini, D. Veronica, S. Whardani, R. Farahmita, A. Tanujaya, E. 2012. Akuntansi Keuangan Menengah, Berbasis PSAK. Buku I, SalembaEmpat, Jakarta.

Pujiati, L., 2015. Pengaruh Penggunaan Modal Kerja Terhadap Tingkat Profitabilitas Pada Perusahaan Sub Sektor Kosmetik Dan Keperluan Rumah Tangga Yang Terdaftar. Eksis: Jurnal Riset Ekonomi dan Bisnis, November, Volume 10, pp. 205-214. 
Respati, H., \& Yandono, P. E. (2008). Tinjauan Tentang Variabel-variabel Camel Terhadap Laba Usaha Pada Bank Umum Swasta Nasional. Jurnal Keuangan dan Perbankan, 12(2), 283-295.

Rudianto, 2012. Pengantar Akuntansi dan Konsep Penyusunan Laporan Keuangan, Adaptasi ISRF. Erlangga, Jakarta.

Sticce, Earl K, Stice, James D and Skousen, K. Fred. 2014. Intermediate Accounting, Edisi ke-16, Buku 2, SalembaEmpat, Jakarta.

Sugiyono. (2010). Metode Penelitian Kuantitatif Kualitatif dan R\&D. Bandung: Alfabeta CV. Sumarjo, H. (2010). Pengaruh karakteristik pemerintah daerah terhadap kinerja keuangan pemerintah daerah (Doctoral dissertation, UNS).

Susilowati, Y. (2011). Reaksi signal rasio profitabilitas dan rasio solvabilitas terhadap return saham perusahaan. Dinamika Keuangan dan Perbankan, 3(1).

Umar, H. (2001). Strategic management in action. Gramedia Pustaka Utama.

Yuwana, V. dan Jogi Cristiawan, Y. (2014). Analisa Kemampuan Laba dan Arus Kas Operasi dalam Memprediksi Arus Kas Operasi Masa Depan. Business Accounting Review, Vol. 2, No. 1. 